\section{The rising incidence of papillary thyroid cancer: More cancers or more assessments?}

Sir,

We read with interest the recent editorial by Aravindan, ${ }^{[1]}$ focusing on the rising incidence of papillary thyroid cancer (PTC) in the Indian state of Kerala. As the author noted, the incidence of PTC is increasing considerably all over the world, and Italy is no exception. The Italian Tumor Registries Association (AIRTUM) ${ }^{[2]}$ recently analyzed the incidence rates of thyroid cancer (TC) in the year 1998 through 2012. The TC age-standardized incidence rates (ASRs) as assessed in the year 1998 through 2002 versus 2008 through 2012, rose by as much as $74 \%$ in women (from 16.2 to $28.2 / 100,000$ ) and by $90 \%$ in men (from 5.3 to $10.1 / 100,000$ ). This increased incidence was due almost exclusively to PTC (up by $91 \%$ in women and $120 \%$ in men). A negligible increase in incidence was seen for follicular and medullary TC, and no significant changes emerged for anaplastic TC. These trends particularly involved high-income regions, with a marked heterogeneity in ASR.

Among the etiopathogenic factors potentially behind TC in India, Aravindan includes both environmental (radiation exposure, iodine intake) and host-related (autoimmunity) issues. On TC etiopathogenesis elsewhere, recent data exclude the possibility of an Italian "PTC epidemy" being due to "new risk factors or greater exposure to known contributors to thyroid cancer,"[3] and the trend is attributed largely to changing PTC assessment procedures (including histology). Vaccarella et al..$^{[3]}$ recently addressed TC epidemiology in several countries (including Italy), specifically comparing cancer incidence registered before and after the advent of ultrasonography (US). Explicitly referring to the extensive use of (mostly "opportunistic") diagnostic procedures (i.e., US), the authors conclude, in referring to the 12 countries considered: "... we estimate that more than 470,000 women and 90,000 men may have been overdiagnosed with thyroid cancer over two decades $[\ldots]$, even though the related mortality rates have remained stable or declined slightly....” 


\begin{tabular}{|c|c|c|c|c|c|}
\hline $\begin{array}{l}\text { Time } \\
\text { interval }\end{array}$ & $\begin{array}{l}\text { Weight of the thyroid } \\
\text { (surgical specimen) }\end{array}$ & $\begin{array}{l}\text { Number of obtained tissue } \\
\text { samples (paraffin blocks) }\end{array}$ & $\begin{array}{c}\text { PTC } \\
\text { prevalence (\%) }\end{array}$ & $\begin{array}{l}\text { Micro-PTC prevalence } \\
\text { (among PTC) (\%) }\end{array}$ & $\begin{array}{l}\text { Largest PTC diameter } \\
\text { (as histologically } \\
\text { assessed) }\end{array}$ \\
\hline $\begin{array}{l}\text { February, } \\
1992\end{array}$ & $\begin{array}{c}\text { Mean }=>36.25 \\
\text { Range }=18-60 \\
S D=14.22\end{array}$ & $\begin{array}{c}\text { Mean }=6.63 \\
\text { Range }=3-12 \\
S D=3.16\end{array}$ & $11 / 20(55)$ & $4 / 11$ (36.3) & $\begin{array}{c}\text { Mean }=1.65 \mathrm{~cm} \\
\text { Range }=0.5-2.6 \\
S D=0.73\end{array}$ \\
\hline $\begin{array}{l}\text { February, } \\
2017\end{array}$ & $\begin{array}{c}\text { Mean }=>36.12 \\
\text { Range }=18-50 \\
S D=15.02\end{array}$ & $\begin{array}{c}\text { Mean }=15.75 \\
\text { Range }=8-24 \\
S D=4.92\end{array}$ & $17 / 20(85)$ & $11 / 17$ (64.7) & $\begin{array}{c}\text { Mean }=0.76 \mathrm{~cm} \\
\text { Range }=0.1-2.2 \\
S D=0.69\end{array}$ \\
\hline$P$ & NS & 0.003 & 0.012 & 0.007 & 0.011 \\
\hline
\end{tabular}

In all cases, a presurgical fine-needle aspiration biopsy of a nodular thyroid lesion had resulted into a cytological diagnosis of "follicular neoplasm." Statistical analyses were performed using the $t$-test. PTC=Papillary thyroid cancer; $S D=S t a n d a r d$ deviation; NS=Not significant

As pathologists electively involved in assessing thyroid neoplastic diseases, we would like to mention another "variable" potentially affecting TC epidemiology, that is, histological examination of thyroidectomy specimens. We hypothesize that the extensive gross sampling of the surgical thyroid specimens, as recommended in last decades, may reveal unsuspected (micro-) cancers (mostly PTC) and thus ultimately prompts a growth in the number of patients with cancer (most of them without any "malignant outcome"). ${ }^{[4]}$ To test this hypothesis, we compared two series of 20 consecutive thyroidectomies performed in February 1992 and February 2017. In all cases, thyroidectomy had been indicated on the grounds of a clinically suspicious nodular lesion, also supported by fine-needle aspiration biopsy (cytological diagnosis of "follicular neoplasm"). In the 1992 series, 55\% of cases were diagnosed as PTC (and the prevalence of micro-PTC among these cancer cases was 36\%), whereas the prevalence of PTC in the 2017 series was $85 \%$ (and the prevalence of micro-PTC among the cancer cases was $85 \%)$. The weights of the thyroid specimen, the sizes, and the numbers of paraffin blocks obtained from the surgical specimens are shown in the Table 1. This pilot test goes to show that over the last 25 years, the number of tissue samples assessed after thyroid surgery has more than doubled, and the prevalence of micro-PTCs among cases of PTC has risen from $36 \%$ to $65 \%$. These findings make it plausible that the recently adopted extensive gross sampling of thyroidectomy specimens may reveal unsuspected microscopic papillary malignancies, potentially contributing to the "PTC epidemic."

Further studies should address whether the histological "opportunistic" overassessment of PTCs (at histology after surgery) may affect the current growth in the incidence of PTC.

Financial support and sponsorship

Nil.

\section{Conflicts of interest}

There are no conflicts of interest.
Francesca Galuppini', Gianmaria Pennelli', Massimo Rugge ${ }^{1,2}$

${ }^{1}$ Department of Medicine (DIMED), Pathology and Cytopathology Unit, University of Padova, ${ }^{2}$ Veneto Cancer Registry, Padova, Italy

Correspondence to:

Massimo Rugge, E-mail: massimo.rugge@ unipd.it

\section{References}

1. Aravindan KP. Papillary thyroid cancer: Why the increase and what can be done? Indian J Cancer 2017;54:491-2.

2. Dal Maso L, Panato C, Franceschi S, Serraino D, Buzzoni C, Busco S, et al. The impact of overdiagnosis on thyroid cancer epidemic in Italy, 1998-2012. Eur J Cancer 2018;94:6-15.

3. Vaccarella S, Franceschi S, Bray F, Wild CP, Plummer M, Dal Maso L, et al. Worldwide thyroid-cancer epidemic? The increasing impact of overdiagnosis. N Engl J Med 2016;375:614-7.

4. Galuppini F, Pennelli G, Vianello F, Censi S, Zambonin L, Watutantrige-Fernando $S$, et al. BRAF analysis before surgery for papillary thyroid carcinoma: Correlation with clinicopathological features and prognosis in a single-institution prospective experience. Clin Chem Lab Med 2016;54:1531-9.

This is an open access journal, and articles are distributed under the terms of the Creative Commons Attribution-NonCommercial-ShareAlike 4.0 License, which allows others to remix, tweak, and build upon the work non-commercially, as long as appropriate credit is given and the new creations are licensed under the identical terms.

\begin{tabular}{|l|l|}
\hline \multicolumn{2}{|c|}{ Access this article online } \\
\hline Quick Response Code: & Website: \\
\hline & www.indianjcancer.com \\
\cline { 2 - 3 } & DOI: \\
\cline { 2 - 2 } & \\
\hline
\end{tabular}

How to cite this article: Galuppini F, Pennelli G, Rugge M. The rising incidence of papillary thyroid cancer: More cancers or more assessments? Indian J Cancer 2019;56:183-4.

(c) 2019 Indian Journal of Cancer | Pulished by Wolters Kluwer - Medknow 